\title{
Does Service Sector Growth Cause Agricultural and Industrial Development? A Dynamic Econometric Approach
}

\author{
${ }^{*}$ Stanley Emife Nwani ${ }^{1}$ \\ Ikechukwu Kelikume ${ }^{2}$ \\ Emeka Osuji ${ }^{1}$ \\ ISchool of Minnigement and Social Sciences, Pan-Itlantic Lniversity, Lagoos, ligeriia \\ 2 Lagos Businesss School, Lagos, ligeriia

\begin{abstract}
This article investigated the service sector linkages with agriculture and industrial sectors with the purpose of ascertaining if forward and backward causal-chain exists, and the direction of causation among these sectors. The study was prompted by obvious evidence that sectoral contributions to growth have defiled the tenets of theories in emerging markets. The study employed a dynamic econometric technique for causaleffect determination in the vector autoregressive (VAR) Granger causality test using annualized time series data on growth rate in service, industry and agriculture sectors between 1982 and 2018. The empirical results revealed a weak sectoral linkage between the service sector and other sectors of the economy. Specifically, service sector growth does not stimulate growth in other sectors but growth in agricultural and industrial sectors drives the service sector performance. This implies that service led growth is illusionary, thus, causes de-industrialization and inhibits agricultural development. On the premises of the empirical findings, the study recommends the need to intensify efforts that would stimulate and establish a synergy between the agricultural and industrial sectors. This will naturally spur growth in the service sector.

Keywords: Service sector, industrial sector, agricultural sector, causality, vector autoregression and econometric approach

JEL: C01, L60, L80, 040
\end{abstract}

Sustaining positive economic growth performance, industrial development, service delivery and food security have continued to be on the front burner of economic, political and socio discussions amongst economic resource planners and researchers especially in emerging market economies (Buckley and Clegg, 2016; Conceição et al., 2016; Gupta and Vegelin, 2016; Rasul and Sharma, 2016; Wade, 2015), this is because sustainable growth and development are products of the interactions amongst various sectors of the economy.

Traditionally, every economy is built around agriculture, industry, and service sectors. The linkage amongst these sectors is such that agricultural sector growth stimulates industrial development which drives the economy towards maturity and in the stage of high and mass consumption, the service sector emerges as a product of industrial sector growth to lead growth episodes and drive the economy towards the stationary state where all economies would converge (Rostow, 1971).

Manuscript received November 26, 2019; revised April 14, 2020; accepted April

23, 2020. @ The Author(s); CC BY-NC; Licensee IJMESS

*Corresponding author: stanleynwani@yahoo.com 
This study attempted an examination of the theoretical validity of the Rostow's theory of growth (Rostow, 1971) and the unbalanced growth model (Baumol, 1967) in a frontier economy from the stand point of Nigeria. Obviously, our findings indicate support for the validity of the latter theory and refutation of the former. This position is buttressed by the evolution of growth trends from agriculture to service-led growth thereby distorting the channels of growth flows.

The agricultural sector is second largest sector in the Nigerian economy with a contribution of 23.76 percent to GDP (Central Bank of Nigeria [CBN], 2018), and consists of four main sub-sectors. The crop production sub-sector plays the lead role in the entire agro space. It contributed a preponderance of 89.74 percent to the total value of agricultural sector output. The agricultural sector also accommodates the livestock sub-sector which accounted for 7.12 percent, the fishery sub-sector yielded 2.10 percent, and the forestry contributed 1.04 percent to agricultural output in Nigeria (CBN, 2018) within the last decade. Statistical evidence further revealed that in 2010 , the value of agricultural output stood at N13.05 billion, out of which crop production sub-sector yielded about N11.68 billion, livestock production generated N0.98 billion, while forestry and fishery contributed N0.136 billion and N0.250 billion, respectively, while in 2018 the situation remains unchanged as proven facts and figures affirm that the crop production sub-sector strengthened its dominance with a contribution of N15.786 billion out of a total sectoral output value of N17.544 billion, while the livestock, forestry and fishery sub-sectors are valued at N1.208 billion, N0.183 billion, and N0.367 billion, respectively. The agricultural sector has as one of its core responsibilities the provision of inputs for the industrial sector development (Prasad, Bhattacharyya and Nguyen, 2017); in spite of the average decent performance of the agricultural sector in recent years, to what extent has it translates into industrial development? This is the first question that yearns for attention in this paper.

The Nigerian industrial sector is classified as the secondary sector with an average contribution of 20.10 percent to the nation's national output between 2010 and 2018 (CBN, 2018). The sector encompasses the crude petroleum and natural gas, solid minerals and manufacturing sub-sectors. The crude oil/natural gas production and the food, beverage and tobacco manufacturing sub-sectors jointly accounts for 88.93 percent of the total value of industrial output, with the crude petroleum/natural gas sub-sector leading the park with a substantive 55 percent contribution to the total industrial output (CBN, 2018). Just as the industrial sector depends on the agricultural sector for inputs, the industrial sector is expected to feed the service sector with finished products for postproduction activities such as marketing, distribution, storage, and sales. The next question that readily comes to mind is how well has the industrial sector satisfied this requirement as the propeller of service sector growth in Nigeria?

Interestingly, the Nigerian service sector has emerged as the largest contributor to the nation's agg- 


\section{Nwani et al.}

regate output in recent decades (see Figure 1) despite the poor run of the industrial sector within the same period. The sector contributed an average of 35.85 percent to the national output within the last decade and has been dubbed as the new engine of growth (Kowalkowski et al., 2015; Rodrik, 2016).

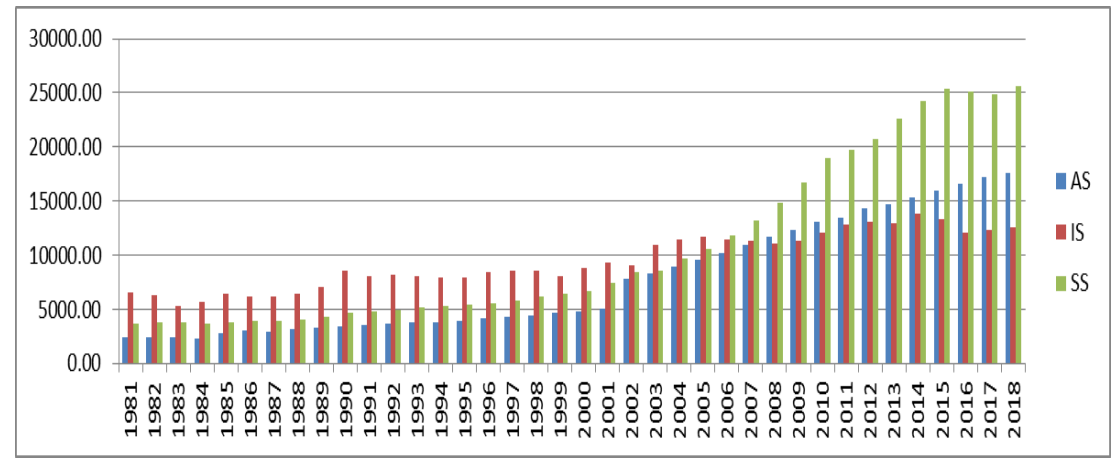

Source: Authors' Computation using CBN Data

Figure 1. Trends in Sectoral Output from 1981 to 2018

It is the broadest sector of the economy and comprises of transportation, information and communication, utilities, finance and insurance, real estate, professional and technical services, business services, public administration, education, health and entertainment sub-sectors. Interestingly, Figure 2 shows that the information and communication (ICT), and the real estate (RE)

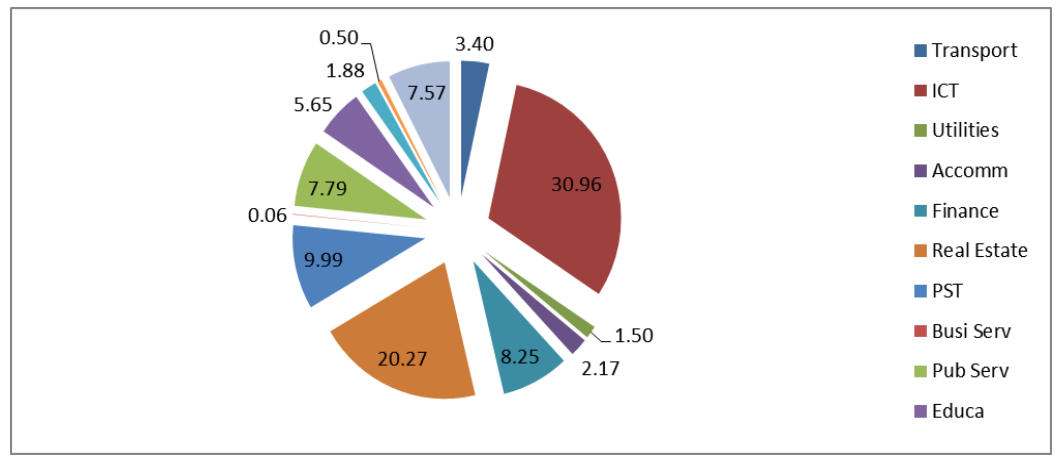

Source: Authors' Computation using CBN Data

Figure 2. Components of the Nigerian Service Sector

sub-sectors stand out as the drivers of the service sector, as ICT contributes 30.96 percent to the total service sector output while real estate follows with a 20.27 percent. Since the Nigerian economy is yet 
to attain the stationary state or the state of conditional convergence, it is expected that the service sector stimulates other sectors of the economy. This leads us to the third question: is there a backward linkage from service sector growth to industrial and agriculture sectors growth?

The remainder of this article is organized as follows. Section 2 contains literature review. Section 3 presents the methodology of the study. Section 4 details out empirical analysis followed by sections presenting discussion of results, conclusion, implications, and limitations and future directions.

\section{LITERATURE REVIEW}

\section{Theoretical Underpinnings}

The earliest work of Clark (1938) laid the foundation for further empirical attention on the role of the service sector in sectoral and aggregate development. At that time, no analytical or theoretical optics existed as service was treated as a different component of production (Kox and Rubalcaba, 2007). As services surge in its contribution to growth, employment, and innovations, it was not until the 1960s when William Baumol established the position that service-led growth could serve as a drag on the growth of other sectors and the entire economy due to its limited potential for sustained productivity. By extension, Baumol's (1967) proposition was corroborated by Hill (1977); thus, the service-led growth has been theoretically seen as an optical illusion which cannot stimulate sustainable growth of the economy nor further the development of other sectors of the economy. Again, the theory postulates that growth in the service sector inhibits agricultural sector output and causes decline of the industrial sector. The application of the unbalanced growth theory of Baumol is evident in the everincreasing portion of the labor force involved in retailing, and an increasing portion of the cost of commodities due to marketing expenditures. Also, with apparent changes in the technology of marketing activities, such as self-service, the supermarket, and pre-wrapping have all increased productivity per staff-hour in the retailing sector. Ultimately, the activity involved is service-oriented, and it does not allow for constant and cumulative increase in productivity through capital accumulation, innovation, or economies of a large-scale operation. Hence it is neither mismanagement nor lack of ingenuity that accounts for the relatively constant productivity of this sector. Since some sort of marketing effort is an inescapable element in economic activity, demand for this service is quite income elastic. Our model tells us what to expect in this case- cumulatively increasing costs relative to those of other economic activities, and the absorption of an ever-growing proportion of society's resources by this sector-precisely what seems observed. Other areas of application of the theory include education and related institutions of service rendering.

\section{Empirical Review}




\section{Nwani et al.}

The Nigerian economy is in the process of structural change characterized by declining share of industry in the economy and rising share of the service sector, but this structural change is not peculiar to Nigeria. Kox and Rubalcaba (2007) argued that in Europe such structural shifts are linked to each other in several ways in the past three decades. Firstly, the fabric of inter-industry relations is being weaved in a new direction due to the growing specialization in knowledge services, the exploitation of economies of scale for human capital lowered costs of in-house outsourcing services, and the everincreasing tertiarization of all production processes, including that of the industry. But in the case of Africa at large and Nigeria in particular, this study argues that such structural shift is as a result of poor governance, lack of industrialization plans, inadequacy of critical pro-industrial infrastructures, unfavorable fiscal policy in terms of multiple taxations, corruption, poor agricultural financing, and overall excessive regulations of industrial activities which leads to industrial sector repression. As such, investment attention has shifted to the service sector where majority of the above-enumerated challenges are not as critical, thus, the increasing contribution of services to economic growth over and above the industrial and agricultural sectors.

In literature, services, agriculture, and industrial sectors linkages have been under-explored using dynamic econometric analysis. Majority of the studies (Chan, Han and Zhang, 2016; Freytag and Fricke, 2017; Saikia, 2011) in this research space employed the input-output analysis based on the unrealistic assumption of structural economic rigidities, while other authors have adopted other methodologies with different empirical results.

At any rate, Kox and Rubalcaba (2007) analyzed the contribution of services to European economic growth using descriptive statistical tools such as table graphs and charts. The study reports that services contribute directly and indirectly to macroeconomic growth in Europe. Specifically, its contribution to employment was massive as it provided more than 50 percent of the gross jobs in Europe. Indirectly, the study documented contributions in terms of knowledge and productivity including positive externalities for other industries. The study concluded that service sector growth has positive effects on industrial and macroeconomic growth in Europe. An analysis of this study revealed that the methodology adopted had the limited capacity to show impact/effects but only indicates trends. If the survey had employed an econometric analysis to examine the relationship, their findings might not have been the same. Again, there are no strong empirical bases for the policy implications of the study. Thus, this study attempts to close this noticeable gap by utilizing an improved methodology.

Using the input-output analysis technique, Saikia (2011) examined the linkages between service sector, agricultural sector. and the industrial sector for India. The author analyzed data that covered before and after reformation era and found that before economic reformation in India, the industrial 
sector feeds the agricultural sector. Interestingly, the interdependency changed after the period of reformation as the agricultural sector took its prominent position feeding the Indian industrial sector with the necessary inputs for development. For the service and industrial sectors, a weak interdependence was reported while a strong services and agricultural sector nexus was found. The implication of the empirical result is such that the Indian economic reformation was able to restructure the economy in line with the appropriate development and growth channels. In a similar analysis for the Chinese economy, Chan, Han and Zhang (2016) examined the inter-sectoral nexus between the real estate sub-sector of the service sector and other sectors economy. The input-output results indicate very strong forward and backward linkages between the real estate sub-sector of the service sector and other sectors of the economy through real and financial channels. The study submits that any shock in the real estate sub-sector has tremendous implications for the stability of the economy. Similarly, in an investigation conducted by Freytag and Fricke (2017) for the Nigerian and Kenyan economies, the issues of intersectoral linkages were empirically investigated based on how the financial services sub-sectors stimulate or drag other sectors with the use of the Leontief input-output method. The empirical result established ample evidence to conclude the existence of strong forward and backward linkages in the Nigerian financial services sector, while weak forward and backward linkages were found for the Kenyan financial services sub-sector. The authors rationalized these results by linking the forward and backward linkages to the underdeveloped nature of the Nigerian financial system and justified the opposing result for the Kenyan economy otherwise. Essentially, the use of the input-output analysis by these studies for sectoral linkages undermines the dynamic features and structural changes in every economy which affects inter-sectoral relationship and dependence. To correct the pitfalls in these studies, the granger causality test which is a dynamic methodology, is utilized in this article; this would help produce a robust result on the dynamism of inter-sectoral dependence.

The Granger causality test improves on the static Leontief approach to inter-sectoral linkages by relaxing its static unrealistic assumption (Granger, 1969). Also, Gemmell, Lloyd and Mathew (1998) was one of the earlier studies to have adopted this technique for a developing economy. The authors examined the linkages amongst service sector, agricultural sector, and the manufacturing sector for Malaysia. Employing time series data, the study documented manufacturing granger causes agriculture, services granger causes agriculture but agriculture does not granger causes manufacturing and services. Thus, a unidirectional causation exists amongst these sectors in Malaysia. Within the same discussion, Subramaniam (2010) employed a panel econometric inter-sectoral linkages analysis for Poland and Romania. The study incorporated the agriculture, manufacturing, services, and trade sectors. The preliminary co-integrating vectors revealed that the analyzed sectors have long-run asso- 


\section{Nwani et al.}

ciation for both economies, which implies an interdependent inter-sectoral growth. In addition, empirical result confirmed that the industrial sector drives agricultural sector, while for the emerging service sector, a mixed result was reported for Poland. In the Romanian economy, the result shows that the industrial sector inhibits agriculture sector while the service sector stimulates agriculture. The study concluded that in the short-run, the service sector propels the growth episode in Poland because of its positive effects on all the other sectors examined. Conversely, industrial sector led-growth hampers other sectors growth in the Polish economy. However, in the Romanian economy, agriculture sector growth has a positive but insignificant impact on industrial sector growth, the study submitted. Though, by analyzing the linkages between manufacturing and other sectors of the Nigerian economy, Salami and Kelikume (2011) employed the Granger causality test. The empirical results indicated a weak interdependence between the manufacturing sector and other sectors of the Nigerian economy. This implies that neither does agriculture Granger causes manufacturing nor manufacturing Granger causes agriculture in Nigeria. In a similar analysis for the Nigerian economy, Sertoglu, Ugura and Bekun (2017) reported that the agricultural output causes long-run growth economic growth using the vector error correction and causality analysis. Lending more voice to the discussion, Gen-xing, ZhengHeng and Lian-Qin (2011) investigated the inter-sectoral relationship between agriculture, industrialization and urbanization in the Chinese economy using the granger causality test on quarterly time series data spanning 15 years, from 1995 to 2009. The study found a unidirectional causality running from agriculture to urbanization and industrialization. This implies that industrialization does not Granger cause the Chinese agricultural sector. The principal conclusion was that majority of the industrial inputs in the Chinese economy are imported from other nations. However, Enyedi and Volgyes (2016) investigated the inter-dependence between agriculture and rural industrializations and found that a unidirectional causality exists that runs from agriculture to rural industrialization and not otherwise amongst selected European economies.

The reviewed literatures show lack of consistency in empirical reports on the causation between the service sector and other sectors of the economy, a gap which this study intends to close. Also, studies on inter-sectoral causation in Nigeria ignored the leading role of the service sector by focusing mainly on agriculture (Sertoglu, Ugura and Bekun, 2017), and manufacturing (Salami and Kelikume, 2011) sectors using historical data set. To improve on these previous studies, this article drew its hypotheses based on service sector growth theory (see Baumol, 1967) using current data set.

This paper relied on the tenets and assumptions of discussed theory and reviewed literature to provide a triangulation for the model specification and hypotheses proposition.

$\mathrm{H}_{01}$ : Agricultural growth Granger causes industrial sector development. 
$\mathrm{H}_{02}$ : Industrial sector growth has forward linkage with services sector growth.

$\mathrm{H}_{03}$ : Service sector growth has backward linkages with industrial and agriculture growth.

\section{METHODOLOGY}

This study examines the service sector linkages with agricultural and industrial sectors for the Nigerian economy. There are different methodological techniques available for intersectoral or sector linkages analysis. The author employed Granger causality test in line with previous studies (Enyedi and Volgyes, 2016; Salami and Kelikume, 2011; Sertoglu, Ugura and Bekun, 2017) which obviously portrays a departure from the traditional Leontief input-output technique. However, this study departs from previous articles by utilizing sectoral output growth rate as against the total sectoral output adopted by previous studies. The methodology employed is dynamic and recognizes the effects of structural changes on sectoral linkages as against the Leontief approach which is static in application.

\section{-Sample and Data}

This study analyzed annual time series data spanning 37 years from 1982 to 2018 for Nigeria. The choice of Nigeria as the sampled economy is based on the fact that from 2010 till date, economic growth trajectory has been driven by the service sector. Thus, it is essential to unravel if service sector growth would cause and sustain growth of the sectors of the economy such as agriculture and industry. In studying service sector linkages with agriculture and industry, the study computed growth rate in service, agriculture, and industrial sectors output as against the absolute values conventionally employed in literature. The sample information is shown in Table 1.

\begin{tabular}{cccc}
\hline Variable & Data & Unit of Measure & Source \\
\hline Service sector & $\begin{array}{c}\text { Annual growth rate in sectoral } \\
\text { output (1982-2018) }\end{array}$ & Percent (\%) & $\begin{array}{c}\text { National Bureau of } \\
\text { Statistics/Central Bank of } \\
\text { Nigeria }\end{array}$ \\
$\begin{array}{c}\text { Agriculture } \\
\text { sector (ASG) }\end{array}$ & $\begin{array}{c}\text { Annual growth rate in sectoral } \\
\text { output (1982-2018) }\end{array}$ & Percent (\%) & $\begin{array}{c}\text { National Bureau of } \\
\text { Statistics/Central Bank of } \\
\text { Nigeria }\end{array}$ \\
$\begin{array}{c}\text { Industrial sector } \\
\text { (ISG) }\end{array}$ & $\begin{array}{c}\text { Annual growth rate in sectoral } \\
\text { output (1982-2018) }\end{array}$ & Percent (\%) & $\begin{array}{c}\text { National Bureau of } \\
\text { Statistics/Central Bank of } \\
\text { Nigeria }\end{array}$ \\
\hline
\end{tabular}

Table 1. Sample Information 


\section{Nwani et al.}

-Model Specification

The general form of the equation is represented thus:

$$
\begin{aligned}
& z_{1 t}=\phi_{1}+\phi_{11} z_{1 t-1}+\Phi_{12} z_{2 t-1}+\Omega_{11} z_{1 t-2}+\Omega_{12} z_{2 t-2}+\epsilon_{1 t} \\
& z_{2 t}=\Omega_{1}+\phi_{21} z_{1 t-1}+\Phi_{22} z_{2 t-1}+\Omega_{21} z_{1 t-2}+\Omega_{12} z_{2 t-2}+\epsilon_{2 t}
\end{aligned}
$$

The compact form of the above VAR equations is expressed in the equation below.

$$
z_{t}=\Omega+\phi_{1} z_{t-1}+\phi_{2} z_{t-2}+\mu_{t}
$$

where

\section{$\Omega$ depicts an $n \times 1$ Column vector}

$\phi_{j ' s}$ are the $\mathrm{n} \times \mathrm{n}$ square metrics

$\mu_{t}$ is an $\mathrm{n} \times 1$ column vector of serially uncorrelated vector of innovations variable which is independently, identically and normally distributed with zero mean and constant variance $\left\{\mu_{t} \sim i i d n\left(0, \sigma^{2}\right)\right\}$.

If $y_{t}$ is a column vector $(n \times 1)$ matrix which encompasses all the lagged variables in the model, which establishes a link between the current $z_{t}$, its lags $\left(z_{t-\mathrm{i}}\right)$ and the white noise variable $\left(\mu_{t}\right)$.

Furthermore, the Granger causality test is employed to estimate equations 4 to 7 which establish sectoral linkages between service sector growth $(S S G)$ with agricultural sector growth $(A S G)$ and industrial sector growth (ISG).

$$
\begin{aligned}
& S S G_{t}=\Omega_{0}+\sum_{t-1}^{n} \Omega_{1} S S G_{t-1}+\sum_{t-1}^{n} \Omega_{2} A S G_{t-1}+\mu_{t} \\
& A S G_{t}=\phi_{0}+\sum_{t-1}^{n} \Phi_{1} A S G_{t-1}+\sum_{t-1}^{n} \phi_{2} S S G_{t-1}+\varepsilon_{t} \\
& S S G_{t}=\beta_{0}+\sum_{t-1}^{n} \beta_{1} S S G_{t-1}+\sum_{t-1}^{n} \beta_{2} I S G_{t-1}+\mu_{t} \\
& I S G_{t}=\alpha_{0}+\sum_{t-1}^{n} \alpha_{1} I S G_{t-1}+\sum_{t-1}^{n} \alpha_{2} S S G_{t-1}+\varepsilon_{t} \\
& A S G_{t}=\gamma_{0}+\sum_{t-1}^{n} \gamma_{1} A S G_{t-1}+\sum_{t-1}^{n} \gamma_{2} I S G_{t-1}+\mu_{t} \\
& I S G_{t}=\vartheta_{0}+\sum_{t-1}^{n} \vartheta_{1} I S G_{t-1}+\sum_{t-1}^{n} \vartheta_{2} A S G_{t-1}+\varepsilon_{t}
\end{aligned}
$$

Given that

$h_{i}=\Omega_{i}, \beta_{i}$ and $\gamma_{i}$

$t_{i}=\phi_{i}, \alpha_{i}$ and $\vartheta_{i}$

From equations 4 to 11 , the following compact forms of null and alternative hypotheses hold. Null hypotheses:

$\mathrm{H}_{0}=\sum_{t-1}^{n} h_{i}=0 ; \mathrm{H}_{0}=\sum_{t-1}^{n} t_{\bar{i}}=0$

The $\mathrm{H}_{0}$ states that SSG does not granger cause $A S G$ and ISG

Alternative hypotheses: 
$\mathrm{H}_{1}=2_{t-1}^{n} h_{i} \neq 0 ; \mathrm{H}_{1}=2_{t-1}^{n} t_{i} \neq 0$

$\mathrm{H}_{1}$ depicts causality running from SSG to $A S G$ and ISG.

-Decision Rule

Statistically significant estimates of $h_{i}$ and $t_{i}$ lead to an evidence of a bi-directional causation. If $h_{i}$ is statistically significant and $t_{i}$ is not, a unidirectional causal relationship will exist running from $S S G$ to other sectors. Again, if $t_{i}$ is statistically significant and $h_{i}$ is not, then a unidirectional relationship will exist that will run from other sectors to SSG. However, the decisions from equations 8 and 9 are directly related to $A S G$ and $I S G$. The test of hypotheses was conducted using the Chi-square and probability values of the pairwise Granger causality technique.

Analyses

-Stationarity Test

Table 2 summarizes the unit root results using the Dickey Fuller (DF), Augmented Dickey Fuller (ADF) and, the Phillips-Perron (PP) techniques. The null hypotheses of non-stationarity were tested at 10 percent, 5 percent and 1 percent levels of significance and the Mackinnon critical values are also shown in Table 2.

\begin{tabular}{|c|c|c|c|c|c|c|c|c|c|c|}
\hline \multicolumn{3}{|c|}{ DF test at levels } & \multicolumn{4}{|c|}{ ADF test in first difference } & \multicolumn{4}{|c|}{ PP test in first difference } \\
\hline Series & No trend & With trend & No trend & Lag & With trend & Lag & No trend & Lag & With trend & Lag \\
\hline SSG & -1.557 & $-3.329^{*}$ & $-.681^{* *}$ & 2 & $-7.116^{* *}$ & 2 & $-9.840^{* *}$ & 2 & $-10.281^{* *}$ & 2 \\
\hline ASG & $-5.798^{* *}$ & $-5.942^{* *}$ & $-5.654^{* *}$ & 2 & $-5.550^{* *}$ & 2 & $-11.760^{* *}$ & 2 & $-11.642^{* *}$ & 2 \\
\hline ISG & $-4.990^{* *}$ & $-5.411^{* *}$ & $-7.471^{* *}$ & 2 & $-7.352^{* *}$ & 2 & $-9.583^{* *}$ & 2 & $-9.581^{* *}$ & 2 \\
\hline
\end{tabular}

Table 2. Unit Root Tests: Nigerian Sectoral Output Growth Data (1982-2018)

From Table 2 and 3, the DF unit root results show that all the data series are stationary at levels with trend, thus we rejected the null hypothesis at 5 percent level of significance. Within the same discussion, the ADF and PP results indicated that all the data series were stationary in first difference. This implies that the differenced data series on the variables are suitable for the empirical analysis to avoid spurious results.

The econometric techniques included the forward-backward sectoral linkage based on Granger causality test is presented in Table 4 and Figure 3, the vector error correction (VECM) estimates 
Nwani et al.

for long-run relationship are presented in Table 5 (see Appendix-I), while the variance decomposition results for short-run and long-run is contained in Table 6 (see Appendix-II).

\begin{tabular}{ccccccc}
\hline DF Test at Levels & & \multicolumn{2}{c}{ ADF Test at First difference } & \multicolumn{2}{c}{ PP Test at First Difference } \\
\hline $\begin{array}{c}\text { Critical value } \\
1 \% \text { level }\end{array}$ & $\begin{array}{c}\text { No trend } \\
\text { - }\end{array}$ & With trend & No trend & With trend & No trend & With trend \\
& & -3.770000 & -3.639407 & -4.252879 & -3.632900 & -4.243644 \\
$5 \%$ level & -1.951000 & -3.190000 & -2.951125 & -3.548490 & -2.948404 & -3.544284 \\
& & & & & & \\
$10 \%$ level & -1.610907 & -2.890000 & -2.614300 & -3.207094 & -2.612874 & -3.204699 \\
\hline Source: Mackinnon (1991)
\end{tabular}

Table 3. Mackinnon Critical Values for Rejection of Unit Root Hypothesis

\begin{tabular}{ccc}
\hline Direction of causality & Lag length & $\boldsymbol{f}$-statistic \\
\hline$\Delta \mathrm{SSG}=>\Delta \mathrm{ISG}$ & 6 & 0.84 \\
$\Delta \mathrm{SSG}=>\Delta \mathrm{ASG}$ & 6 & 0.41 \\
$\Delta \mathrm{ASG}=>\Delta \mathrm{SSG}$ & 1 & $7.03^{*}$ \\
$\Delta \mathrm{ASG}=>\Delta \mathrm{ISG}$ & 6 & 0.60 \\
$\Delta \mathrm{ISG}=>\Delta \mathrm{SSG}$ & 1 & $11.90^{* *}$ \\
$\Delta \mathrm{ISG}=>\Delta \mathrm{ASG}$ & 6 & $2.76^{*}$ \\
\hline
\end{tabular}

Source: Authors' Computation using EViews 10

Note: ${ }^{*}$ and ${ }^{* *}$ denote rejection of the null hypothesis at $p<.05$ and $p<.01$, respectively.

$\Delta \mathrm{x}=>\Delta \mathrm{y}$ implies sector $\mathrm{x}$ granger causes sector $\mathrm{y}$.

Table 4. Causality Tests of Service Sector on Other Sectors of the Nigerian Economy

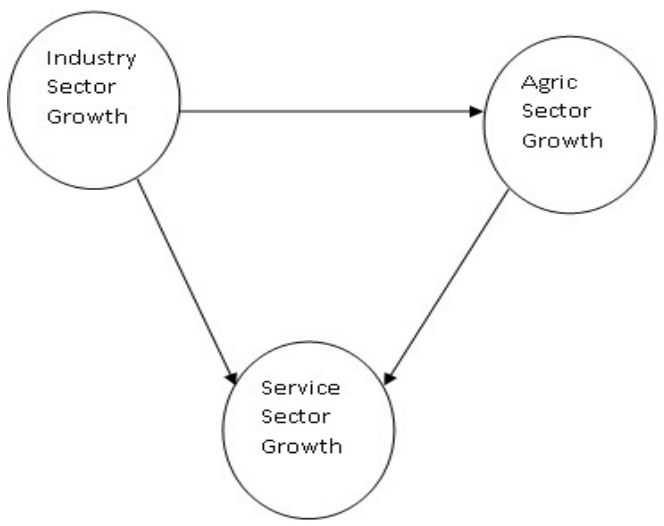

Source: Authors' Presentation from Causality Results

Figure 3. Causal Linkages among Service, Agriculture and Industrial Sectors in Nigeria

DISCUSSION 
This study applied the Granger causality test to ascertain whether growth in service sector output growth precedes the growth of agricultural and industrial sector outputs. The results as presented in Table 4 indicate that the service sector growth does not Granger cause growth in agriculture and industrial sectors. This is because the service sector does not add value to industrial and agricultural products but only responsible for marketing, distribution, and sales of the products (Rathore et al., 2019). Interestingly, growth in agricultural and industrial sectors Granger causes service sector growth. Empirically, there exists a unidirectional relationship between service sector growth and agricultural and industrial sectors. Specifically, it takes one quarter for the growth in industrial and agricultural sectors to trigger service sector growth. It means that agricultural and industrial sectors have immediate multiplier effects on the growth of the service sector. The paper's empirical findings validate Baumol (1967) unbalanced growth theory, and refute Rostow (1971) stages theory of growth. Furthermore, agriculture and industrial sectors growth exhibit unidirectional relationship. The agricultural sector precedes industrial sector growth and the reversal is not applicable. However, it takes six quarters for the growth in agricultural output to stimulate industrial output. The lack of linkage from industrial sector growth to agriculture could be rationalized on the basis that a preponderance of industrial output goes to the final demand sector; this means that very little proportion of industrial products serves as agricultural input.

To further validate the outcome of this study, VECM estimates and variance decomposition estimates were obtained for long-run analysis presented in Table 5 and 6 , respectively. The former reveals that service sector growth does not significantly impact on growth in the outputs of industry and agriculture. Also, the impact of growth in agricultural output on the output of the industry sector is not significant. But, growth in agriculture and industry outputs has positive impact on services. The result of variance decomposition test reinforces our earlier findings of lack of backward linkages from services to industry and agriculture. From Table 6, innovations in service sector account for 5.58 percent and 14.98 percent of the changes in industrial and agricultural outputs, respectively.

From the empirical results and discussions, $\mathrm{H}_{01}$, which states that agricultural growth Granger causes industrial sector development is refuted, while the alternative hypothesis that industrial growth causes agricultural sector development is accepted. The unbalanced growth theory (Baumol, 1967) and other empirical studies (Gemmell, Lloyd and Mathew, 1998; Subramaniam, 2010), but disagrees with the submissions of Gen-xing et al. (2011) that agricultural sector growth leads to the development of the industrial sector.

Also, $\mathrm{H}_{02}$ that industrial sector growth has forward linkage with service sector growth is accepted. The implication of the acceptance and its justification is supported by both the unbalanced and stages theories (Baumol, 1967; Rostow, 1971). Empirical justification is drawn from Salami and Kelikume 


\section{Nwani et al.}

(2011). Finally, the third null hypothesis, $\mathrm{H}_{03}$ that service sector growth has backward linkages with industrial and agriculture growth is refuted. Thus, service sector growth does not feed back into industry and agriculture due to its weak, illusionary, and unsustainable nature. The lack of service sector linkages with industry and agriculture is supported by the positions of Baumol unbalanced growth theory, and Saikia (2011) that reported a weak interdependence between service sector and other sectors of the economy. However, this submission is a sharp departure from what Kox and Rubalcaba (2007) found for European economies.

\section{CONCLUSION}

This study investigates the causal linkages among service, agriculture and the industrial sectors in Nigeria. It departs from previous inter-sectoral analysis by measuring sectors by the growth rate in outputs against the value of their contributions to GDP. Country specific data sourced from the CBN were analyzed using a dynamic econometric method. The conclusion drawn from the empirical result is that there is an unbalanced flow of economic activities among the three sectors analyzed. Also, the specific lead-lag time frame required for innovation in one economic sector to affect growth in other sectors is of great essence to policymakers and investors alike.

To the policymakers, it should be noted that growth enhancing policies in the service sector does not translate to sustainable growth in the agricultural and industrial sectors. Thus, the service sector does not feed the agricultural and industrial sectors. This is because the service sector does not add value to industrial and agricultural products; neither does it provide critical inputs for agriculture and industrial processes.

\section{IMPLICATIONS}

The study shows that there are no bi-causal linkages between the service sector, agricultural, and the industrial sector. Overall, a weak sectoral linkage exists in the flow of economic activities in the Nigerian economy. This gives rise to unbalanced growth - a situation where the service sector propels the economy at the expense of agricultural and industrial development. The theoretical implications of this finding are significant. First, the study validates Baumol's unbalanced growth theory and strengthens its application for sectoral planning in frontier and emerging market economies. Second, African and Asian economies with similar structural, economic, and social characteristics as Nigeria should be wary of the unsustainable growth trajectory of the service sector as postulated in Baumol's unbalanced growth theory. The empirical evidence from this study points towards poor service sector linkage with the agricultural and industrial sectors. This affirmation differs from Gemmell, Lloyd and 
Mathew (1998) that reported a unidirectional causality from service to industry and agriculture for Malaysian economy, and Saikia's (2011) finding that the India's service sector leads the agricultural sector. Our findings further disagreed with Gen-xing et al. (2011) who reported a lack of industrial sector feedback to agriculture in the Chinese economy. Thus, our findings are novel and a rebirth of the unbalanced growth theory.

The results of this study also have practical implications for investment decision makers. Investor whose industrial processes rely on agricultural inputs must plan the dynamics of their operations in line with the 18 months periods required for every agricultural output to fit into industrial needs. For agroindustrialists, they should be aware that the Nigerian industrial sector does not provide inputs that are significantly relevant to agro-businesses, thus, agro-investors should be able to plan their businesses in such a way that it is adaptable and flexible enough for inputs requirements.

For public policymakers and the Nigerian government, there is an urgent need to reposition the industrial and agricultural sectors as the engines of sustainable growth. This could be done through training of farmers, provision of modern farm inputs and technologies, improving infrastructure base such as energy, transportation and communication facilities.

\section{LIMITATIONS AND FUTURE DIRECTIONS}

The main limitation of this study is its country-specific approach, which makes generalization difficult if not impossible. Future studies should extend the scope of this article to cover emerging economies across the world using a panel analysis. Such panel analysis should include a minimum of 30 emerging and frontier economies across Africa, Asia, Europe, and North America. Both short-run and long-run estimates and relationship should be determined. The panel Pedroni cointegration analysis should be conducted to determine intersectoral linkages in the long-run. The suitability and appropriateness of fixed and random effects estimates could be ascertained using the Haussman test. Ultimately, such study would provide a robust validation of whether service sector causes growth in agriculture and industrial sectors in different social and economic environments.

\section{REFERENCES}

Baumol, W. (1967) Macroeconomics of unbalanced growth: The anatomy of urban crisis. American Economic Review, 57, 415426.

Buckley, P. J. \& Clegg, J. (2016). Multinational enterprises in less developed countries. Cambridge Journal of Economics, 13(1): 103-120.

Central Bank of Nigeria (2018). Statistical bulletin. Retrieved November 20, 2019, from http://www.cbn.gov.ng

Chan, S., Han, G. \& Zhang, W. (2016). How strong are the linkages between real estate and other sectors in China? Research in International Business and Finance, 36, 52-72. https://doi.org/10.1016/j.ribaf.2015.09.018

Clark, C. (1938). Australian economic progress against a world background. In J. Fisher (Eds), Australia's economy in its international context. 443-474. Australia: University of Adelaide Press.

Conceição, P., Levine, S., Lipton, M. \& Warren-Rodríguez, A. (2016). Toward a food secure future: Ensuring food security for sustainable human development in Sub-Saharan Africa. Food Policy, 60, 1-9. 


\section{Nwani et al.}

Enyedi, G. \& Volgyes, I. (2016). The effect of modern agriculture on rural development: comparative rural transformation series. USA: Elsevier.

Freytag, A. \& Fricke, S. (2017). Sectoral linkages of financial services as channels of economic development-An input- output analysis of the Nigerian and Kenyan economies. Review of Development Finance, 7(1): 36-44. https://doi.org/10.1016/j.rdf.2017.01.004

Gemmell, N., Lloyd, T. \& Mathew, M. (1998). Dynamic sectoral linkages and structural change in a developing economy, CREDIT Research Paper, No. 98/3, The University of Nottingham, Centre for Research in Economic Development and International Trade (CREDIT), Nottingham.

Gen-xing, P. A. N., Zhen-heng, L. I. N. \& Lian-Qin, L. (2011). Perspective on biomass carbon industrialization of organic waste from agriculture and rural areas in China. Journal of Agricultural Science and Technology, 13(1): 75-82.

Granger, C. W. (1969). Investigating causal relations by econometric models and cross-spectral methods. Econometrica: Journal of the Econometric Society, 37(3): 424-438. https://doi.org/10.2307/1912791

Gupta, J. \& Vegelin, C. (2016). Sustainable development goals and inclusive development. International Environmental Agreements: Politics, Law and Economics, 16(3): 433-448.

Hill, T. P. (1977). On goods and services. Review of income and wealth, 23(4): 315-338. https://doi.org/10.1111/j.14754991.1977.tb00021.x

Kowalkowski, C., Windahl, C., Kindström, D. \& Gebauer, H. (2015). What service transition? Rethinking established assumptions about manufacturers' service-led growth strategies. Industrial Marketing Management, 45, 59-69. https://doi.org/10.1016/j.indmarman.2015.02.016

Kox, H.L.M. \& Rubalcaba L (2007) Analysing the Contribution of Business Services to European Economic Growth. Bruges European Economic Research Papers. Available at: http://www.coleurop.be/eco/publications.htm

MacKinnon, J. G. (1991). Critical values for cointegration tests. In R. F. Engle and C. W. J. Granger (Eds.), In Long-run Economic Relationships: Readings in Cointegration: 267- 276. Oxford: Oxford University Press.

Prasad, R., Bhattacharyya, A. \& Nguyen, Q. D. (2017). Nanotechnology in sustainable agriculture: recent developments, challenges, and perspectives. Frontiers in Microbiology, 8, 10-14. https://doi.org/10.3389/fmicb.2017.01014

Rasul, G. \& Sharma, B. (2016). The nexus approach to water- energy- food security: An option for adaptation to climate change. Climate Policy, 16(6): 682-702.

Rathore, K., Shahid, R., Ali, K. \& Saeed, A. (2019). Factors affecting service sector's contribution to GDP in Pakistan. Pakistan Vision, 20(2): 175-190.

Rodrik, D. (2016). Premature deindustrialization. Journal of Economic Growth, 21(1): 1-33. https://doi.org/10.1007/s10887015-9122-3

Rostow, W. W. (1971). Politics and the stages of growth. Cambridge: Cambridge University Press.

Saikia, D. (2011). Analyzing inter-sectoral linkages in India. African Journal of Agricultural Research, 6(33): 6766-6775. https://doi.org/10.5897/AJARX11.024

Salami, D. \& Kelikume, I. (2011). Empirical analysis of the linkages between the manufacturing and other sectors of the Nigerian economy. WIT Transactions on Ecology and the Environment, 150, 687-698. https://doi.org/10.2495/SDP110571

Sertoglu, K., Ugural, S. \& Bekun, F. V. (2017). The contribution of agricultural sector on economic growth of Nigeria. International Journal of Economics and Financial Issues, 7(1): 547-552.

Subramaniam, V. (2010). Agricultural intersectoral linkages and their contribution to economic development. Published doctoral dissertation 771, University of Kentucky. Lexington, United States. Available at: https://uknowledge.uky.edu/gradschool_diss/771

Wade, N. (2015). A troublesome inheritance: Genes, race and human history. UK: Penguin Books. 


\begin{tabular}{|c|c|c|c|}
\hline Cointegrating Eq: & CointEq1 & & \\
\hline $\operatorname{SSG}(-1)$ & 1.000000 & & \\
\hline ISG(-1) & $\begin{array}{c}7.990813 \\
(1.99569) \\
{[4.00404]}\end{array}$ & & \\
\hline ASG(-1) & $\begin{array}{r}-2.707328 \\
(1.29125) \\
{[-2.09667]}\end{array}$ & & \\
\hline $\mathrm{C}$ & -10.60423 & & \\
\hline Error Correction: & D(SSG) & D(ISG) & D(ASG) \\
\hline CointEq1 & $\begin{array}{c}-0.005270 \\
(0.02407) \\
{[-0.21900]}\end{array}$ & $\begin{array}{c}-0.180244 \\
(0.04479) \\
{[-4.02422]}\end{array}$ & $\begin{array}{r}0.001127 \\
(0.08507) \\
{[0.01325]}\end{array}$ \\
\hline $\mathrm{D}(\mathrm{SSG}(-1))$ & $\begin{array}{c}-0.217518 \\
(0.19672) \\
{[-1.10571]}\end{array}$ & $\begin{array}{c}0.219523 \\
(0.36612) \\
{[0.59959]}\end{array}$ & $\begin{array}{l}0.318551 \\
(0.69540) \\
{[0.45809]}\end{array}$ \\
\hline $\mathrm{D}(\mathrm{SSG}(-2))$ & $\begin{array}{r}-0.238673 \\
(0.18087) \\
{[-1.31959]}\end{array}$ & $\begin{array}{c}0.209349 \\
(0.33662) \\
{[0.62191]}\end{array}$ & $\begin{array}{l}0.270024 \\
(0.63936) \\
{[0.42234]}\end{array}$ \\
\hline D(ISG(-1)) & $\begin{array}{c}0.132210 \\
(0.13089) \\
{[1.01010]}\end{array}$ & $\begin{array}{r}0.432827 \\
(0.24360) \\
{[1.77680]}\end{array}$ & $\begin{array}{r}0.261967 \\
(0.46268) \\
{[0.56620]}\end{array}$ \\
\hline $\mathrm{D}(\mathrm{ISG}(-2))$ & $\begin{array}{r}0.033187 \\
(0.09846) \\
{[0.33707]}\end{array}$ & $\begin{array}{c}0.061531 \\
(0.18324) \\
{[0.33579]}\end{array}$ & $\begin{array}{r}0.161981 \\
(0.34804) \\
{[0.46540]}\end{array}$ \\
\hline $\mathrm{D}(\mathrm{ASG}(-1))$ & $\begin{array}{r}-0.123977 \\
(0.08054) \\
{[-1.53934]}\end{array}$ & $\begin{array}{r}-0.173391 \\
(0.14989) \\
{[-1.15676]}\end{array}$ & $\begin{array}{r}-0.681588 \\
(0.28470) \\
{[-2.39406]}\end{array}$ \\
\hline $\mathrm{D}(\mathrm{ASG}(-2))$ & $\begin{array}{l}0.049780 \\
(0.06733) \\
{[0.73935]}\end{array}$ & $\begin{array}{r}-0.103520 \\
(0.12531) \\
{[-0.82612]}\end{array}$ & $\begin{array}{r}-0.421627 \\
(0.23800) \\
{[-1.77151]}\end{array}$ \\
\hline $\mathrm{C}$ & $\begin{array}{c}0.058878 \\
(0.57582) \\
{[0.10225]}\end{array}$ & $\begin{array}{r}-0.317114 \\
(1.07168) \\
{[-0.29590]}\end{array}$ & $\begin{array}{c}0.213488 \\
(2.03548) \\
{[0.10488]}\end{array}$ \\
\hline R-squared & 0.517627 & 0.633049 & 0.400365 \\
\hline Adj. R-squared & 0.387757 & 0.534255 & 0.238925 \\
\hline Sum sq. resids & 290.6403 & 1006.717 & 3631.729 \\
\hline S.E. equation & 3.343422 & 6.222531 & 11.81871 \\
\hline F-statistic & 3.985737 & 6.407740 & 2.479958 \\
\hline Log likelihood & -84.72125 & -105.8414 & -127.6527 \\
\hline Akaike AIC & 5.454191 & 6.696555 & 7.979569 \\
\hline
\end{tabular}


Nwani et al.

\begin{tabular}{cccc} 
Schwarz SC & 5.813335 & 7.055698 & 8.338712 \\
Mean dependent & 0.145039 & -0.149254 & 0.191323 \\
S.D. dependent & 4.272965 & 9.117858 & 13.54741 \\
\hline Determinant resid covariance $(d f$ adj. $)$ & 53446.90 & \\
Determinant resid covariance & 23900.44 & \\
Log likelihood & -316.1198 & \\
Akaike information criterion & 20.18352 & \\
Schwarz criterion & 21.39563 & 27 \\
Number of coefficients & 27 & \\
\hline
\end{tabular}

Source: Authors' Computation using EViews 10

Table 5. Vector Error Correction Estimates (Long-Run Analysis) 


\begin{tabular}{|c|c|c|c|c|}
\hline Period & S.E. & SSG & ISG & ASG \\
\hline 1 & 3.343422 & 100.0000 & 0.000000 & 0.000000 \\
\hline 2 & 4.256153 & 89.37114 & 2.345797 & 8.283062 \\
\hline 3 & 4.861794 & 87.47495 & 2.610345 & 9.914706 \\
\hline 4 & 5.380754 & 89.23074 & 2.633478 & 8.135778 \\
\hline 5 & 5.836257 & 89.78642 & 2.272062 & 7.941515 \\
\hline 6 & 6.257748 & 90.82485 & 2.052504 & 7.122649 \\
\hline 7 & 6.645169 & 91.80556 & 1.872660 & 6.321781 \\
\hline 8 & 7.007215 & 92.53125 & 1.690135 & 5.778619 \\
\hline 9 & 7.355451 & 93.16336 & 1.581339 & 5.255297 \\
\hline 10 & 7.684023 & 93.70561 & 1.478697 & 4.815698 \\
\hline \multicolumn{5}{|c|}{ Variance Decomposition of ISG } \\
\hline Period & S.E. & SSG & ISG & ASG \\
\hline 1 & 6.222531 & 0.948657 & 99.05134 & 0.000000 \\
\hline 2 & 7.272427 & 3.967840 & 72.70457 & 23.32759 \\
\hline 3 & 7.775487 & 4.654780 & 69.49877 & 25.84645 \\
\hline 4 & 7.943074 & 4.527596 & 66.79157 & 28.68083 \\
\hline 5 & 8.316944 & 4.472221 & 60.95699 & 34.57079 \\
\hline 6 & 8.509589 & 4.905602 & 58.25760 & 36.83680 \\
\hline 7 & 8.717395 & 5.193295 & 55.55398 & 39.25273 \\
\hline 8 & 9.010767 & 5.260474 & 52.12178 & 42.61775 \\
\hline 9 & 9.219987 & 5.383501 & 49.79501 & 44.82148 \\
\hline 10 & 9.420310 & 5.542043 & 47.70519 & 46.75277 \\
\hline \multicolumn{5}{|c|}{ Variance Decomposition of ASG } \\
\hline Period & S.E. & SSG & ISG & ASG \\
\hline 1 & 11.81871 & 10.22594 & 0.524610 & 89.24945 \\
\hline 2 & 12.64687 & 12.60698 & 1.697930 & 85.69509 \\
\hline 3 & 13.69944 & 14.33646 & 1.487267 & 84.17628 \\
\hline 4 & 15.97347 & 13.41904 & 2.275774 & 84.30519 \\
\hline 5 & 16.91560 & 13.86033 & 2.037948 & 84.10172 \\
\hline 6 & 17.88950 & 14.37919 & 1.823316 & 83.79749 \\
\hline 7 & 19.12869 & 14.47896 & 1.717236 & 83.80381 \\
\hline 8 & 20.07625 & 14.70625 & 1.609286 & 83.68447 \\
\hline 9 & 20.98918 & 14.89441 & 1.508385 & 83.59720 \\
\hline 10 & 21.93914 & 14.98667 & 1.432367 & 83.58097 \\
\hline
\end{tabular}

Source: Authors' Computation using EViews 10

Table 6. Variance Decomposition of SSG, ISG, and ASG 